\title{
Conventional and Rubberize Concrete Cylinders Filled with PVC Tube
}

\author{
Faizullah Jan ${ }^{1}$, Amjad Naseer ${ }^{2}$ Muhammad Fahadullah ${ }^{3}$, Hammad Akbar $^{4}$ \\ $1,2,4$ University of Engineering and Technology Peshawar, Pakistan \\ ${ }^{3}$ City University of Science and Information Technology (CUSIT) Peshawar \\ engrfaizullahjan@gmail.com ${ }^{1}$, amjad_naseer@yahoo.com ${ }^{2}$, engr.fuzi@gmail.com ${ }^{3}$, hamadakbar10@gmail.com ${ }^{4}$ \\ Received: 26 April, Revised: 02 May, Accepted: 03 May
}

\begin{abstract}
The use of composite materials poly-vinyl chloride (PVC) in construction were studied. The use of PVC plastic pipe for concrete tubing is an alternative to use instead of concrete encased in steel tube and hence improve strength, ductility, durability, economical and environmental friendly. The key application of PVC tubing was its use in high aggressive environments and stop the penetration of chlorine and carbon dioxide directed towards core concrete and defect core concrete. Although the use of PVC as a composite materials in aggressive environments are efficient but PVC behave like brittle materials. The main parameters discussed are geometric and materials properties of thin PVC, stay-inplace formwork, PVC tubing from conventional concrete and rubberize concrete, confinement.
\end{abstract}

Keywords - Polyvinyl Chloride, Rubberize Concrete, PVC Jacket, Composite Structure And External Confinement.

\section{INTRODUCTION}

Maintain the fortification and durability of new RC structures in aggressive and saline environments are a challenge for designers and engineers. There are many techniques used for protection of concrete and its reinforcement from harsh and aggressive environments. The use of PVC tubing is an effective, easy, economical way to protect reinforced concrete from chlorination and carbonation. PVC tube prevents construction practices from expensive curing process, protect concrete and its reinforcement by deter core concrete from moisture which have a role in setting and hydration of plastic concrete, make concrete impermeable and give lateral confinement to concrete. PVC tubing is state of the art new confining technique for structural engineers to overcome the exposing of core concrete to saline environments. This research study includes the parameters of PVC plastic tube encased conventional and rubberize concrete that influences the performance of composite materials structures.

\section{A. Poly-vinyl Chloride (PVC) Tube}

PVC is a polymer found universally having certain excellent applications in construction industries. The PVC deformation mechanism is still not clarify [1]. Research has been carried out to examine the short and long term ageing behaviour of FRP and PVC in 28 different organic compounds with extreme aggressive environmental condition for 112 days.
Due to chemical reactions FRP degraded and PVC shows good performance as compared with FRP and are not degraded [2]. Observation based on stress degradation, PVC fatigue and crack growth expansion the design life of PVC can exceeded 100 years [3-7]. Due to its good mechanical stability and molecular structure PVC has a wide role in commercial usage [8]. Toughness due to fracture depends upon the molecular structure of polymers [9]. PVC tube filled with water test under concentrically indirect axial load to determine the slenderness behavior both experimentally and theoretically [11]. Due to use of polymer alloys Indulin Lignin the mechanical properties of PVC tube can also be enhanced [12]. The impact behaviour of PVC was found to increase incorporating chlorinated polyethylene (CPE) and acrylonitrile-butadiene-styrene (ABS) sub-polymers [13]. The geometrical and mechanical properties influences the deformation of buckling and axial capacity of non-metallic and metallic tubes $[15,16]$. When PVC was compared with metallic steel tubes, PVC is lighter in weight as compared to steel tube, more economical and its thermal conductivity are $0.40-0.55 \%$ lower as compared to steel tube $[5,18]$.

\section{B. Crumb Rubber Concrete (CRC)}

Crumb rubber concrete obtained from truck scrape tyres and replace a percentage of fine aggregate in making concrete. Due to huge amount of scrape tyres used in land infill make environmental concerns each year [34]. When tyre build up stocks exposed to fire then it is difficult to extinguish and release harmfull chemicals to environment [35]. Tyre store deposits reduce biodiversity due to soluble noxious chemicals [36]. If we used scrap tyres in conventional concrete to replace natural assets it will reduce demands on land infill and environmentally friendly [6]. However the rubberize concrete (crumb rubber concrete-CRC) has low tensile and compressive strength. CRC has also low modulus of elasticity as compared with conventional concrete [37,38]. The advantage of CRC over conventional concrete are better energy dissipation, ductility, make it more durable with good toughness and impact resistance [39, 40]. Despite its good mechanical properties its an another way to dispose off hazardous waste by replacing with natural resources in concrete and make it environmentally-friendly. 


\section{Non-Metallic PVC Jacket}

PVC encasement provides a protection jacket to its infill concrete. In a research study the tubular concrete sunken into concentrated sea water having twenty times more concentrated than natural sea water for 180 days [19]. The post observation of experiments reveal that there is no major change in chemical composition and microstructure when exposed to harsh saline environments. The above mention studies indicates the performance of PVC in construction industry.

\section{GEOMETRIC AND MATERIALS PROPERTY OF PVC TUBE}

The geometrical properties of PVC tube from existing research studies are shown in TABLE I.

TABLE I. PROPERTIES OF PVC TUBE

\begin{tabular}{|c|c|c|c|c|c|c|c|}
\hline Authors & $\begin{array}{l}\mathbf{t} \\
\mathbf{m m}\end{array}$ & $\begin{array}{l}\mathrm{D} \\
\mathrm{mm}\end{array}$ & $D / t$ & $\begin{array}{l}\mathbf{E} \\
\text { Mpa }\end{array}$ & $\begin{array}{l}\mathbf{F}_{\mathbf{y}} \\
\text { MPa }\end{array}$ & $\begin{array}{l}\mathbf{F}_{\mathbf{u}} \\
\mathbf{M P a}\end{array}$ & $u$ \\
\hline $\begin{array}{l}\text { Alves and } \\
\text { Martins [1] }\end{array}$ & 1.7 & 40 & 23.53 & 2450 & & 54 & 0.34 \\
\hline $\begin{array}{lr}\text { Kwon } & \text { and } \\
\text { Truss } & \text { [9] } \\
\text { UPVC } & \end{array}$ & 14.5 & 150 & 10.34 & 3100 & 45 & 45 & \\
\hline UniOPVC & 5 & 160 & 32 & 4100 & 65 & 101 & \\
\hline BiOPVC & 5 & 160 & 32 & 3800 & 65 & 94 & \\
\hline \multirow[t]{2}{*}{ Kurt [20] } & 4.8 & 76 & 15.83 & 2760 & & 40.90 & \\
\hline & 6.4 & 100 & 15.60 & 2760 & & 40.90 & \\
\hline \multirow[t]{2}{*}{ Saadoon [21] } & 3.2 & 110 & 34.40 & 2770 & & 49.60 & \\
\hline & 5.3 & 110 & 20.75 & 2770 & & 49.60 & \\
\hline \multirow[t]{2}{*}{$\begin{array}{l}\text { Rahai et al. } \\
\text { [22] }\end{array}$} & 4.3 & 90 & 20.93 & 3000 & & 55 & \\
\hline & & & & & & 88 & \\
\hline \multirow[t]{3}{*}{$\begin{array}{l}\text { Wang and } \\
\text { Yang [18] }\end{array}$} & 3.7 & 110 & 29.73 & 3000 & 45 & & \\
\hline & 5.2 & 110 & 21.15 & & & & \\
\hline & 8.5 & 110 & 12.94 & & & & \\
\hline 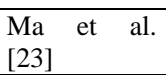 & 4.5 & 200 & 44.44 & & & 44 & 0.36 \\
\hline $\begin{array}{l}\text { Jiang et al. } \\
{[24]}\end{array}$ & 4.5 & 200 & 44.44 & & & 42.50 & 0.36 \\
\hline $\begin{array}{l}\mathrm{Wu} \text { et al. } \\
{[25]}\end{array}$ & 4.5 & 200 & 44.44 & & 44 & & 0.36 \\
\hline \multirow{3}{*}{$\begin{array}{l}\text { Oyawa et al. } \\
\text { [26] }\end{array}$} & 2.5 & 110 & 40 & 3380 & 39.96 & & 0.38 \\
\hline & 3 & 83 & 27.66 & 3380 & 39.96 & & 0.38 \\
\hline & 2.5 & 55 & 22 & 3380 & 39.96 & & 0.38 \\
\hline \multirow[t]{2}{*}{$\begin{array}{lll}\text { Xue } & \text { et } & \text { al. } \\
{[27]} & & \\
\end{array}$} & 2.3 & 75 & 32.60 & 3075 & & 20.20 & \\
\hline & 3 & & 36.66 & 3315 & & 19.56 & \\
\hline \multirow[t]{3}{*}{$\begin{array}{l}\text { Chen at al. } \\
{[28]}\end{array}$} & 3 & 32 & 10.66 & 2520 & & 107 & 0.36 \\
\hline & 2 & 50 & 25 & & & & \\
\hline & 2.3 & 75 & 32.60 & & & & \\
\hline $\begin{array}{l}\text { Fakharifar } \\
\text { and Chen } \\
{[29]}\end{array}$ & 7.1 & 166 & 23.38 & 4030 & 41.30 & 50.36 & 0.419 \\
\hline
\end{tabular}

PVC tensile strength have been obtained from PVC coupon test in axial direction as shown in Figure (a). The uniaxial and biaxial oriented PVC (UniOPVC \& BiOPVC) pipes were tested in tangential direction as shown in Figure (b) and concluded that UniOPVC and BiOPVC shows good behaviour in post-yielding load [9]. The critical buckling load was determined [1] as shown in Figure 1(a) and further investigated that additional instability (additional folds) were produced due to deformations [24]. The axial deformation curves was shown in Figure 1 (b).
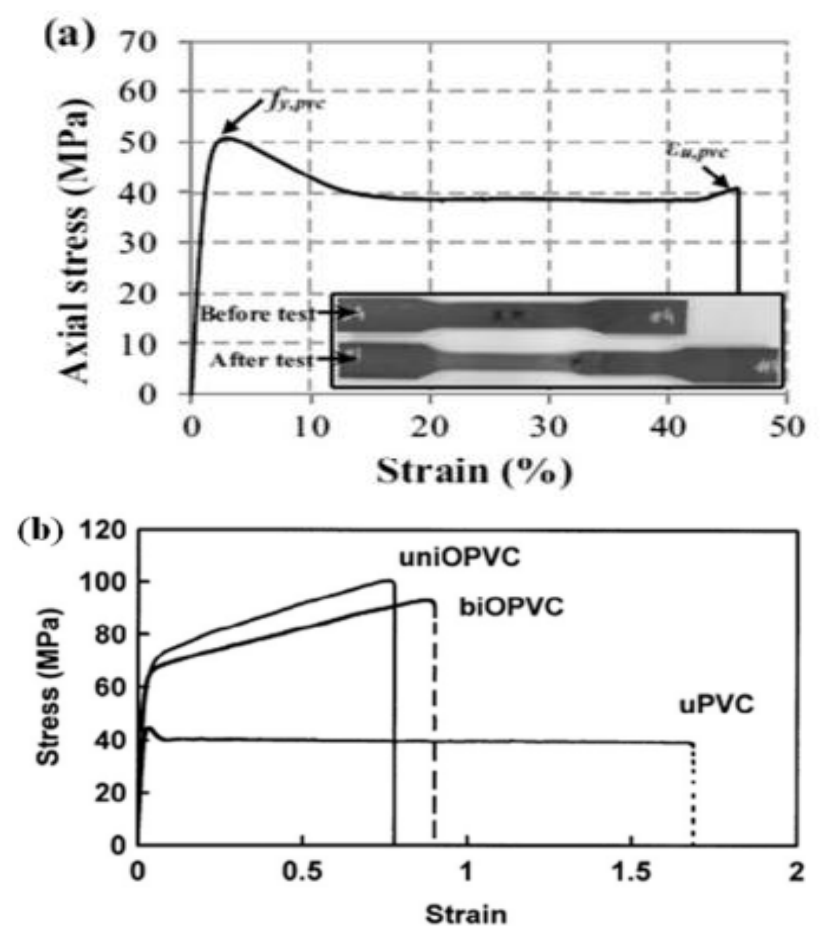

Figure I. (a), (b) Tensile stress-strain curve of coupon test: (a) axial direction [29] (b) tangential direction [9].
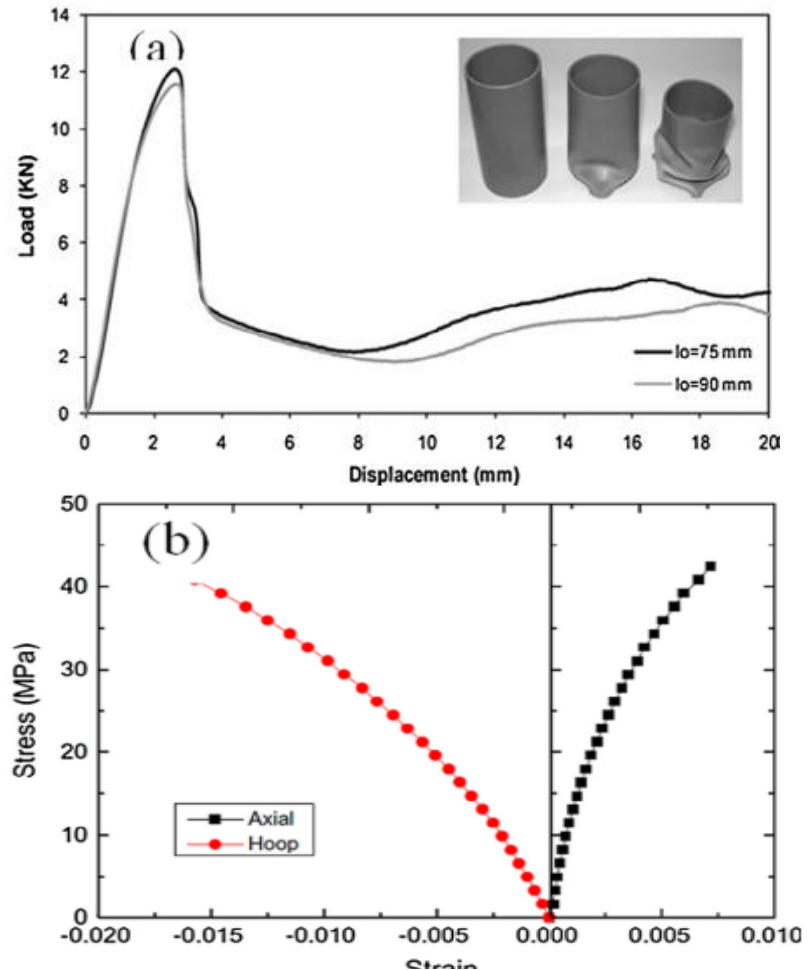

Figure 1 (a), (b): (a) Load-displacement curve [1] (b) Stress-strain curve [24]

The cost ratio of PVC compared with steel are half and very much less than FRP. PVC undergo longer deformation 
due to its good elastic properties. Being a low stiffness, modulus of elasticity of PVC (Ep) are lower than $50 \%$ of modulus of elasticity of steel. The nominal confining ratio (flu/fuc) ratio of schedule-40 PVC pipe filled with concrete is 0.08 [29], where flu $=$ lateral confinement pressure and fuc $=$ Unconfined concrete strength. This level of confinement is 50 $\%$ of confinement provided by 1 layer of CFRP wrap from concrete cylinder. However the combine use of CFRP and PVC resists to local buckling between PVC and core concrete due to wrapping of CFRP [30, 31].

\section{AXIAL DEFORMATION CAPACITY}

Rubberize concrete slightly increase the peak strength with a decrease in ultimate drift ratio when concrete confined with PVC tube as compared with conventional unconfined concrete [16]. Concrete cylinder confined with PVC exhibit brittle behavior with a sudden loss of axial load capacity, by introducing an energy impact medium rubberize concrete enhances the load-deformation behavior with strain-softening in second part of the stress-strain curve [29]. Axial load capacity of short concrete columns were increased by $3.3 \%$ and its behaviour is similar to that of column internally confined with spiral reinforcement, while the columns fail due to hoop tension and axial compressive stresses [20]. The strength and deformation capacities of 12 concrete short columns after tested in axial compression show virtuous retort when paralleled with control specimen [21]. Mechanical characteristics of PVC confined concrete columns with partial replacement (20\%-30\%) of blended silica fumes were also evaluated [24]. The strength of PVC confined concrete columns were increased with $1.18 \%-3.65 \%$ when compared with control specimen [25].

\section{SEISMIC PERFORMANCE}

Composite materials are frequently used in civil engineering construction and industries. Composite materials enhances the seismic performance of civil engineering structures. Cyclic test were performed on rubberize concrete confined with PVC tube, it was recommended that PVC is the best substitute instead of metallic steel tubes to resist seismic forces [32]. The seismic performance of PVC confined concrete tube and steel tube confinement were calculated and observe shear diagonal compression failure. It was also investigated that column confinement with PVC and steel tubes exhibits large axial deformation capacity and high ultimate strength, however the ductility could reduce with the increase in thickness of PVC tube [32]. Concrete columns filled with PVC tube yields good strength and ductility, also the wrapping of CFRP from PVC confined concrete enhance the strength and ductility and shows good hysteresis behaviour under reverse cyclic loadings [35].

\section{CONCUSLION}

PVC tube act as pre-installed protection jacket for core concrete. PVC used in research shows high ductility, good bearing capacity, used in normal and saline environment, good thermal and electrical conductivity, time saving, economical, light weight and more durable. The ductility and strength depends upon the compressive strength of core concrete, tube geometry, thickness of tube and slenderness ratio.

\section{REFERENCES}

[1] L.M. Alves, P.A.F. Martins, Cold expansion and reduction of thinwalled PVC tubes using a die, J. Mater. Process. Technol. 209 (9) (2009) 4229-4236.

[2] T.A. Ranney, L.V. Parker, Susceptibility of ABS, FEP, FRE, FRP, PTFE, and PVC Well Casing to Degradation by Chemicals, Special Report, 95-1: US Army Corps of Engineers, 1995.

[3] A. Boersma, J. Breen, Long term performance prediction of existing PVC water distribution systems: 9th International Conference PVC: Brighton: England (2005).

[4] J. Breen, Expected lifetime of existing water distribution systemsmanagement summary, TNO Report MT-RAP-06-18692/MSO, published by TNO Science and Industry (2006).

[5] R. Nowack, O.I. Otto, E.W. Braun, 60 jahre erfahrungen mit rohrleitungen aus weichmach-erfreiem polyvinylchlorid (PVC-U), KRV Nachrichten (1995) 1-95.

[6] S. Burn, P. Davis, T. Schiller, Long-term performance prediction for PVC pipes, American Water Works Association AWWARF; Report 91092F (2006).

[7] S. Folkman, Validation of the long life of PVC pipes, in: Proceedings of the $17^{\text {th }}$ Plastic Pipes Conference PPXVII. Chicago; Illinois: USA (2014).

[8] M.V. Titow, PVC Technology, Springer, 1984.

[9] J.A. Kwon, R.W. Truss, The work of fracture in uniaxial and biaxial oriented unplasticised polyvinylchloride pipes, Eng. Fract. Mech. 69 (5) (2002) 605-616.

[10] M.M. Carroll, Polyvinylchloride (PVC) pipe reliability and failure modes, Reliab. Eng. 13 (1) (1985) 11-21.

[11] M. Motavalli, M. Farshad, P. Flueler, Buckling of polymer pipes under internal pressure, Mater. Struct. 26 (6) (1993) 348-354.

[12] S.E.1. Raghi, R.R. Zahran, B.E. Gebril, Effect of weathering on some properties of polyvinyl chloride/lignin blends, Mater. Lett. 46 (6) (2000) 332-342.

[13] L. Zhou, X. Wang, Y. Lin, J. Yang, Q. Wu, Comparison of the toughening mechanisms of poly(vinyl chloride)/chlorinated polyethylene and poly(vinyl chloride/acrylonitrile-butadiene-styrene copolymer blends, J. Appl. Poly. Sci. 90 (4) (2003) 916-924.

[14] M.P. Kruijer, L.L. Warnet, R. Akkerman, Analysis of the mechanical properties of a reinforced thermoplastic pipe (RTP), Compos. Part A: Appl. Sci. Manufact. 36 (2) (2005) 291-300.

[15] A.A.N. Aljawi, Finite element and experimental analysis of axially compressed plastic tubes, Belgium Soc. Mech. Environ. Eng. 45 (1) (2000) 3-10.

[16] A. Mamalis, D. Manolakos, M. Loannidis, P. Kostazos, C. Dimitriou, Finite element simulation of the axial collapse of metallic thin-walled tubes with octagonal cross-section, Thin-Walled Struct. 41 (10) (2003) 891-900.

[17] Yu. K. Morozov, E.V. Ashraf, K. Shankar, Buckling behavior of reinforced thermo-plastic pipes under combined external pressure and bending: 8th Australian congress on applied mechanics (ACAM8) 2014: Melbourne.

[18] J.Y. Wang, Q.B. Yang, Investigation on compressive behaviors of thermoplastic pipe confined concrete, Constr. Build. Mater. 35 (2012) $578-585$.

[19] P.K. Gupta, V.K. Verma, Study of concrete-filled unplasticised polyvinyl chloride tubes in marine environment, Proc. Inst. Mech. Eng. Part M J. Eng. Maritime Environ. (2014). 1475090214560448.

[20] E.C. Kurt, Concrete filled structural plastic columns, Proceedings ASCE104 ST1 (1978) 55-63.

[21] A.S. Saadoon, Experimental and Theoretical Investigation of PVCConcrete Composite Columns (Doctoral dissertation), University of Basrah, Iraq, 2002. 
[22] A.R. Rahai, M.M. Alinia, S.M.F. Salehi, Cyclic performance of buckling restrained composite braces composed of selected materials, Int. J. Civ. Eng. 7 (1) (2009) 1-8.

[23] S. Ma, S. Jiang, Study on behavior of concrete-filled CFRP-PVC tubular slender columns under axial compression, China Civ. Eng. J. 1 (2014) 99-106.

[24] S. Jiang, S. Ma, Z. Wu, Experimental study and theoretical analysis on slender concrete filled CFRP-PVC tubular columns, Constr. Build. Mater. 53 (2014) 475-487.

[25] W. Wu, Q. Lin, S. Jiang, Study on the behavior of concrete-filled FRPPVC tubular flexural members, Eng. Mech. 32 (6) (2015) 104-110.

[26] W.O. Oyawa, N.K. Gathimba, G.N. Mang'uriu, Innovative composite concrete filled plastic tubes in compression: The 2015 World Congress on Advances in structural engineering and mechanics (ASEM15) Incheon, Korea, 2015.

[27] J. Xue, H. Li, L. Zhai, X. Ke, W. Zheng, B. Men, Analysis on influence parameters and mechanical behaviors of embedded PVC pipe confined with reinforced high-strength concrete columns under cyclic reversed loading, Xi'an University of Arch. \& Tech. (natural science edition), 48(1), 2016.

[28] Y. Chen, R. Feng, L. Xiong, Experimental and numerical investigations on steel- concrete-PVC SHS joints under axial compression, Constr. Build. Mater. 102 (2016) 654-670.

[29] M. Fakharifar, M.G. Chen, Compressive behavior of FRP-confined concretefilled PVC tubular columns, Compos. Struct. 141 (2016) 91109.

[30] H. Toutanji, M. Saafi, Durability studies on concrete columns encased in PVC-FRP composite tubes, Compos. Struct. 54 (1) (2001) 27-35.

[31] J.G. Teng, Y.M. Hu, Suppression of local buckling in steel tubes by FRP jacketing, in: Proceedings, Second International Conference on FRP Composites in Construction, Adelaide, Australia 2004.

[32] A. Rteil, K. Soudki, D. Richardson, Flexural behavior of OctaformTM forming system, ACI SP 257 (9) (2008) 133-148.

[33] A.H. Chahrour, K.A. Soudki, J. Straube, RBS polymer encased concrete wall. Part I: experimental study and theoretical provisions for flexure and shear, Constr. Build. Mater. 19 (7) (2005) 550-563.

[34] K.G. Kuder, R. Gupta, C.H. Jones, R. Hawksworth, S. Henderson, J. Whitney, Effect of PVC stay-in-place formwork on mechanical performance of concrete, J. Mater. Civ. Eng. 21 (7) (2009) 309-315.

[35] N. Wahab, K.A. Soudki, Flexural behavior of PVC stay-in-place formed RC walls, Constr. Build. Mater. 48 (2013) 830-839. 